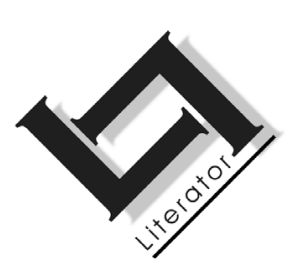

\title{
Die moderne self as toneelpop in Woyzeck on the Highveld ${ }^{1}$
}

\author{
A. Krueger \\ Department Drama \\ Rhodes Universiteit \\ GRAHAMSTAD \\ E-pos: a.krueger@ru.ac.za
}

\section{Abstract \\ The modern self as puppet in Woyzeck on the Highveld}

This article undertakes a semiotic investigation of identifications of the self in terms of a specifically South African modernism, via an exploration of an adaptation of Georg Büchner's "Woyzeck". William Kentridge's production of "Woyzeck on the Highveld" (1992; 2009) marks at least three intersections of modernist and modernising discourses. Firstly, it uses as its principal source Georg Büchner's protomodernist text, with its description of an individual alienated from his social context. Secondly, in making use of the puppets of the Handspring Puppet Company for its central characters, the play employs a style commensurate with modernist aesthetics, in terms of the objectification of subjectivity and the mechanisation of the subject. Thirdly, by re-contextualising Büchner's German soldier as an African mineworker, the production deals with aspects of modernisation by examining the clash, confusion and concomitant syncretism of rural and urban cultures. The article concludes by identifying the all too human desire to be more than a puppet, more than machine, and the potential consequences of the fragmented modernist self on conceptions of identity and freedom.

1 'n Vorige weergawe van hierdie artikel is vir die eerste keer aangebied tydens die International Federation of Theatre Research Conference onder die tema "Cultures of Modernity" in München, Duitsland, 26-31 Julie 2010. Die vertaling is deur Marike Beyers, met verdere hulp deur Sonja Smit en Tim Huisamens. Dankie ook aan M. Kruger (Universiteit van Stellenbosch) vir haar nuttige opmerkings, waarvan heelwat in die artikel geïnkorporeer is. 


\section{Opsomming}

\section{Die moderne self as toneelpop in Woyzeck on the Highveld}

Hierdie artikel onderneem 'n semiotiese ondersoek na die identifikasie van die self spesifiek in die Suid-Afrikaanse modernisme deur 'n verwerking van Georg Büchner se "Woyzeck" as vertrekpunt te neem. William Kentridge se produksie van "Woyzeck on the Highveld" (opgevoer in 1992 en in 2009) verteenwoordig ten minste drie raakpunte tussen modernistiese en moderniserende diskoerse. Eerstens is die toneelstuk se hoofbron Georg Büchner se protomodernistiese teks waarin 'n Deur die toneelpoppe van Handspring Puppet Company as sentrale karakters te gebruik, word tweedens 'n styl na vore gebring wat verskeie elemente van die modernistiese estetika oproep, naamlik die objektivering van subjektiwiteit en die meganisering van die subjek. Deur Büchner se Duitse soldaat te rekontekstualiseer as 'n Afrika-mynwerker, bring die toneelstuk derdens verskeie aspekte van modernisering na vore deur die botsing, verwarring en die gepaardgaande sinkretisme van plattelandse en stedelike kulture te ondersoek. Ten slotte word verwys na die mens se strewe om meer te wees as net 'n toneelpop, meer as 'n masjien, asook die moontlike gevolge wat die gefragmenteerde modernistiese self kan hê vir konsepte van menslike vryheid en identiteit.

\section{Inleiding: toneelpoppe en modernisering in Suid- Afrika}

Die rol van poppespel het gedurende die laaste aantal jare meer prominent geword in die Suid-Afrikaanse teater. Hoewel baie mense die idee van poppespel moontlik nog steeds assosieer met moraliserende kinderverhale, het daar in die laaste tyd 'n opmerklike verskuiwing plaasgevind. Dat Janni Younge, as poppemeester, die Standard Bank Jong Kunstenaarprys vir Drama gewen het, dui op die groeiende erkenning van poppespel. Sy is ook kurator van Out the Box, die poppespelfees wat nou al sy agste jaar in Kaapstad beleef. Verdere belangstelling in poppespel blyk uit die uitmuntende boek wat die Handspring Puppet Company in 2010 in samewerking met David Krut vrygestel het en waarin hulle werk van die afgelope dertig jaar gevier word. Daarbenewens het nagraadse studente, meestal aan die Universiteit Stellenbosch, ook etlike tesisse oor die rol van poppespel in die Suid-Afrikaanse konteks voltooi (vgl. Du Preez, 2007; Smalberger, 2011). 
Om 'n mens te vervang met'n objek of simbool is 'n modernistiese neiging. Die toneelpop is deur talle modernistiese kunstenaars gebruik, byvoorbeeld Picasso, Cocteau, Paul Klee en die kunstenaars van De Stijl. Baie modernistiese kunstenaars deel 'n voorliefde vir "puppets, marionettes, automatons and related forms of human likenesses" (Segel, 1995:322). ${ }^{2}$ Dit hou verband met dit wat Frederic Jameson (2002) noem "depersonalisation, that moment from subjective expression to objecthood", en dit is "a fundamental feature of modernity and modernism alike" (Jameson, 2002:152-153). Die moderne lewe is een van regulering en die manipulasie van beweging. Dit word gekenmerk deur die ritme van objekte, masjiene, skedules; kwaliteite wat onlosmaaklik deel is van die toneelpop se bestaan. ${ }^{3}$ Miskien lê die oorsaak van hierdie objek-wees gedeeltelik in die industrialisering van die werksmag en die koms van die fabriek, wat die self ' $n$ rat, 'n eenheid, 'n item in 'n gemeganiseerde vervoerband maak. Met die opkoms van die kapitalisme het die self 'n ding geword.

Handspring se Woyzeck on the Highveld (1992; 2009) is 'n toneelstuk wat hierdie modernistiese belangsteling in die objektivering van die self bondig uitbeeld. Daar is ' $n$ hele reeks stylfigure uit die modernisme en moderniteit wat mekaar in hierdie produksie kruis. Eerstens is die toneelstuk se hoofbron Georg Büchner (1971 [1879]) se protomodernistiese teks, wat 'n vervreemde individu. uitbeeld. Deur toneelpoppe as voorstelling vir die sentrale figure te gebruik, word tweedens 'n styl gebruik wat verskeie elemente van modernistiese estetika oproep, met spesifieke verwysing na Segel se beskrywing in Pinocchio's progeny (1995). Derdens bring die toneelstuk verskeie aspekte van modernisering in Suid-Afrika na vore deur Büchner se soldaat te rekontekstualiseer as 'n myntrekarbeider.

Büchner se teks was miskien die eerste toneelstuk wat die tragedie van die gewone mens uitgebeeld het. Gekonfronteer met onoorkombare teenslae word 'n figuur met 'n lae sosiale status meegesleur in 'n maalkolk van kulturele, godsdienstige en sielkundige magte. Dit kan as die eerste ware moderne toneelstuk beskou word,

2 Dit sluit ook robotte en masjiene in, alhoewel daar 'n verskil is tussen die robot en die toneeepop. Robotte is meganies van aard (selfs al is dit net in die verbeelding van die gehoor), terwyl die toneelpoppe in die verbeelding van die gehoor oor 'n vorm van lewe beskik.

3 Dit is moeilik om jou in te dink hoe verbasend en ondermynend dit eens moes gewees het om 'n mens deur 'n bewegende masjien te laat voorstel, veral toe toneelpoppe lank gelede met afgode vergelyk is (Du Preez, 2007:51-52). 
omdat dit demonstreer dat ons lewens bepaal word deur sosiale omgewingsomstandighede en erflikheid. Die besluit om toneelpoppe in die Suid-Afrikaanse weergawe van Woyzeck on the Highveld te gebruik om hierdie identifisering te demonstreer, stel William Kentridge in staat om die objektivering van die self en die meganisering van die subjek na vore te bring.

In Suid-Afrika het die moderne ervaring van objektivering nie heeltemal op dieselfde manier as in Europa plaasgevind nie, aangesien daar eerder 'n mynrovolusie as 'n industriële rewolusie in die land plaasgevind het. Deur Woyzeck 'n rondtrekkende mynwerker in die vyftigerjare van die vorige eeu te maak, word dit moontlik om kommentaar te lewer op die verskillende magte wat die Suid-Afrikaanse nasie tot stand gebring het - aangesien niks die koms van moderniteit in hierdie land so duidelik inlui as die totstandkoming van die mynbedryf nie. Grootskaalse mynwerk het begin met die ontdekking van diamante aan die oewers van die Oranjerivier in 1867, dertig jaar na Büchner se dood en twaalf jaar voor Woyzeck die eerste keer gepubliseer is. Die mynwese het Suid-Afrika geïndustrialiseer en lê aan die hart van die moderniseringsproses wat hier plaasgevind het. Dit was die myne waaroor in die Anglo-Boereoorlog geveg is. Dit was ook ter wille van die myne dat landelike bevolkings geplunder is vir werkers wat as trekarbeiders hulle gesinne en tradisies verlaat het om nuwe identiteite onder die aarde uit te grawe. Dit is op die mynwese dat die ryk, veeltalige kultuur van baie van die land se belangrike stede gebou is. Dit maak dus sin om die ontstaan en vroeë ontwikkeling van die mynwese in Suid-Afrika met moderniteit te verbind.

Voordat die raakpunte tussen poppespel, moderniteit en die konstruksies van die self verder ondersoek word, moet die storie van Woyzeck on the Highveld kortliks opgesom word. Twee fragmente uit die verhoogproduksie word daarna ontleed.

\section{Woyzeck on the Highveld}

Woyzeck kom in Johannesburg aan, 'n landskap wat deur William Kentridge in sy bekende houtskool animasie-agtergrondsketse uitgebeeld word as dor en verlate. Woyzeck se houvrou, Maria, by wie hy 'n kind het, word deur 'n frisgeboude mynwerker verlei. Woyzeck word onderwerp aan eksperimente en preke deur Dokter, wat behep is daarmee om hom ertjies te voer en sy urine te analiseer en die moraliserende Kaptein, wat uitwei oor die waardes van dit wat die 
"Verligting" of rasionele beskawing genoem sou kon word. Kaptein 4 maak uitsprake oor deugsaamheid en oor hoe belangrik dit is om binne die sfeer van die kerk te leef; die smal weg te loop; om nie rond te haas nie, en dergelike dinge. Albei hierdie figure vertoon aspekte van die waansin van moderniteit - van die absurde pogings om orde te probeer handhaaf in 'n wêreld wat lostol uit sy wentelbaan, om W.B. Yeats se metafoor in "The second coming" te gebruik.

Woyzeck word innerlik al hoe meer weerloos. Hy voel omsingel deur kragte wat hy oral rondom hom sien - die kragte van status, geld en mag. Dokter en Kaptein probeer aanhoudend sy individualiteit beklemtoon, maar hy sien homself gestroop van sy eie mag deur die samelewing; as iemand uit balans met die natuur en toenemend buite sy eie beheer. Soos hy verder geobjektiveer word, versplinter sy self. Wanneer hy sy houvrou met die myner sien dans, staan hy verslae. Woyzeck konfronteer die myner en kom sleg daarvan af. Hy soek vertroosting in die naghemel en nadat hy een aand 'n mes in die sterre sien, vermoor hy vir Maria.

Die eerste van die twee tonele in Woyzeck on the Highveld wat ek in meer detail bespreek, is aan die begin van die verhoogproduksie waar gesien word hoe Woyzeck met 'n etenstafel baklei. Kentridge se ruwe houtskoolanimasie gee 'n verbeeldingryke agtergrond vir wat in Woyzeck se gedagtes aangaan wanneer hy probeer eet onderwyl hy geleidelik beheer oor die proses verloor. In hierdie toneel kom die poppespelers vir die eerste keer fisies op die verhoog. Tot op hierdie stadium het Woyzeck soos 'n selfstandige figuur gelyk, maar hier word hy omring deur maniipulerende mense. Dit is vreemd dat Woyzeck amper meer outonoom voorkom binne hierdie konteks van ander wesens. In plaas daarvan dat hulle die gehoor se aandag van Woyzeck aflei, skep die Aankondiger 5 en die

$4 \quad$ "Kaptein" en "Dokter" staan sonder 'n lidwoord, omdat hulle die name van figure in die teks aandui.

$5 \quad$ Aankondiger word vir die Engelse term Barker gebruik. In 'n algemene sin verwys dit na iemand wat 'n vertoning op straat adverteer of mense van die straat af inroep. Dit kan ook in melodramas verwys na 'n karakter wat deur 'n megafoon vanaf die verhoog met die gehoor praat, selfs instruksies gee (soos in Woyzeck). Die Afrikaanse term reklameroeper sou wel die promosie-aspek insluit, maar terselfdertyd die verhoogaspek verloor. Verhoogroeper (of dalk Verhoogbek - wat dalk iets van die voorbarigheid van "Barker" behou) sou meer spesifiek wees, maar obskuur. Aankondiger is dus 'n woord wat met sy assosiasies die rol van die karakter aandui, ietwat soos 'n seremoniemeester of vertellerfiguur. 
twee poppespelers eerder 'n gevoel van outentisiteit in die spel asof die toneelpoppe onafhanklik bestaan van die mense rondom hulle.

In hierdie toneel probeer Woyzeck om 'n geordende etenstafel te bemeester met goeie etiket en mooi tafelmaniere. Die lewelose voorwerpe begin egter die maaltyd omverwerp. Dit is 'n baie modernistiese oomblik wanneer voorwerpe magtiger as hulle meesters word; wanneer voorwerpe buite beheer glip. Woyzeck se tafel is teen die einde besaai met kos en industriële voorwerpe: instrumente vir kommunikasie, vervoer en handel wat onverpoos sy pogings om enigiets in te neem, onderbreek met verdere begeertes, met meer en meer. Hier soen 'n mens die detritus van industrialisasie wat sy behoefte aan lewensmiddele oorrompel.

In 'n verdere toneel word Woyzeck deur Dokter ondersoek. Wanneer hy met 'n instrument in hom probeer sien, ontdek Dokter dat hulle elkeen ander musiek hoor en 'n ander wêreld sien. Hy hoor binne-in Woyzeck die liedjies van sy veraf dorpie, maar ook die geroesemoes van die myne, die geskel van huisdiere, en die brokstukke van die moderne wêreld wat binne hom rondmaal. In 'n animasiesekwens van Kentridge word gewys hoe Woyzeck vertroosting vind in die sterre, en dié wys vir hom wat sy hart hom vertel - dat hy die mes moet optel.

In 'n sekere sin kan die besluit om Maria te vermoor as 'n poging tot bevryding gesien word - 'n ontsnapping uit die belaglike strik van magte wat rondom hom uitspeel. Aan die begin en aan die einde van die toneelstuk beskryf onderskeidelik die Aankondiger, Kaptein en Dokter die storie as "a beautiful murder". Miskien is dit omdat die moord hulle werk weer sinvol maak: skielik het hulle teoretisering 'n objek om te ontleed.

Woyzeck se wil word gestel, nie net teen Maria nie, maar ook teen die wêreld, teen die myner, Kaptein, Dokter en die stelsel. Die toneelstuk kan gesien word as 'n mislukte poging om nie alleenlik teen die wêreld uit te vaar nie, maar teen 'n lewensbeskouing, 'n Weltanschauung. In 'n seker sin is Woyzeck soos Pinocchio, soos alle toneelpoppe wat van vryheid droom, net om uit te vind dat dit teen 'n verskriklike prys verkry word. Soos Pinocchio, is Woyzeck 'n rebelse toneelpop. Hy verlang daarna om selfstandig te wees, dat sy lewe nie bepaal sal word deur sy armoede en sy stand nie. Sy liefde en sy jaloesie is egter hiermee verwikkeld en hy pleeg moord in 'n toestand van wanhoop - want geen ontsnapping uit die samelewing 
is moontlik nie, geen uitkoms uit die lewensbeskouing waarin hy homself bevind nie.

\section{Die modernistiese self as toneelpop}

Een van die sleutelbegrippe van die moderniteit en modernisme behels die konfigurasie van die modernistiese individu as ' $n$ versplinterde self, afgesny van sy verlede. Een van die sleuteldefinisies van die moderne self is in 1844 die eerste deur Karl Marx verwoord in die Paris manuscripts (1988), naamlik Entfremdung. Dit is 'n term wat die situasie van die moderne mens in 'n wêreld van masjiene paslik beskryf: vervreemd van sy werk, sy tradisies en sy gemeenskap. Die mynwerkers op wie se rug die Suid-Afrikaanse stedelike samelewing gebou is, bied gepaste voorbeelde van hierdie proses waardeur die self gestroop word van selfbeskikking. Deur die oprigting van die myne in Suid-Afrika en die oorloë wat daarop gevolg het, is die gevoel van identiteit en samehorigheid van baie mense in Suid-Afrika op gewelddadige wyse vernietig.

Hierdie verskeurde, gefragmenteerde self word gekoppel aan die koms van die modernisme. Susan Bordo (1996) definieer die opkoms van die modernistiese self as ' $n$ "parturition from the organic universe of the Middle Ages and Rennaissance". Hierdie skeiding het gelei tot "the modern categories of 'self' ... and 'innerness"' (Bordo, 1996: 641). Dit is miskien vreemd om te dink dat die beweging na "innerness" gekoppel is aan die gevoel van vervreemding (alienation). Die self word ontdek in die oomblik van voorwerp-word. Dit is moontlik dat daar geen ander manier vir die individu is om homself te vind sonder die teenoorgestelde gevoel van vervreemding nie. Die self word dus ontdek juis deur die vervreemding van die self.

Teen die agtergrond van Taylorisme en die gepaardgaande meganisasie van gedrag - die gevolg van aspirasies na doeltreffendheid - kan toneelpoppe gesien word as lewende masjiene; as ikonies van die voorwerpe waarin mense deur kapitaal verander word. 6 Die toneelpop is egter 'n eienaardige tipe masjien, want dit ondermyn 
een van moderniteit se sleutelwaardes, naamlik doeltreffendheid (iets wat vandag nog oor die algemeen vanselfsprekend as 'n deug aanvaar word). Gerhard Marx (2009) ondersoek hierdie paradoks in 'n essay getiteld "The function of malfunction" in die onlangse boek wat oor Handspring geskryf is. Hier definieer hy toneelpoppe as "exomatic organs" - liggaamsdele buite die liggaam. Die hoofuitgangspunt van die essay is dat die voorwerp ook 'n werkwoord kan wees - 'n handeling wat binne die veld van "semiotic fluidity" funksioneer, in plaas daarvan om slegs 'n "material solidity with determined qualities" te wees (Marx, 2009:226). Met verwysing na 'n interpretasie van Heidegger, beskryf Marx die oomblik wat 'n voorwerp wanfunksioneer as die oomblik wanneer die voorwerp se fisiese, materiële aard duidelik na vore kom. Tot dan word die voorwerp slegs geken "through its use, only as a means to an end" (Marx, 2009:230). Wanneer dit nie meer funksioneer nie, word die voorwerp iets op sy eie - dit is dan wanneer "the object's physicality becomes present" (Marx, 2009: 236). Marx gebruik die voorbeeld van 'n motorkar of 'n ketel wat ophou werk. Wanneer dit werk, is dit onsigbaar, slegs 'n middel tot 'n doel. Wanneer dit egter ophou werk, word ons bewus van die massa van die motor, die ruimtelike teenwoordigheid daarvan. Marx (2009:236) sê dit is "as if we need to kill the tool to make the object come to life". In hierdie opsig is sigbare wanfunksie meer waardevol op die verhoog as vloeiende funksionering en om suksesvol te wees, moet die toneelpop, paradoksaal, 'n wanfunksionele instrument word.

Die toneelpoppe wat Kohler vir Woyzeck on the Highveld gemaak het, dien as beelde en as voorstellings van figure (en natuurlik ook idees). Die toneelpop is 'n gemaakte voorwerp en tog, omdat dit lewe gegee word, bly dit nie net 'n beeldhouwerk nie .

[O]nce it enters into performance it is constantly re-formed by its changing semiotic and gestural context, and so its form arguably never actually settles. ... [l]t is the idea of the thing (not the thing) which is collectively manifested manipulated and altered in the space between object, puppeteer and audience ... it is the malleable idea of the thing (once divorced from singular function) that is the true medium of the puppeteer. (Marx, 2009:240-241.)

Marx voer aan dat die poppespeler nie net met 'n voorwerp werk nie, maar met 'n idee. Terwyl hy met 'n materiële voorwerp werk, werk hy ook binne 'n diskoers. Frederic Jameson (2002:138) vind dat "[t]he very movement towards language itself, in modernist practice as well as in contemporary philosophy betrays this obligatory 
detour through the object world, that is, through matter and space." Hierdie uitspraak versterk die idee dat die toneelpoppe voorwerpe is wat gebruik word om oor idees te praat.

Die toneelpoppe in Woyzeck vestig die aandag op hulleself as voorwerpe, identiteite en dinge. Die regisseur, Kentridge, het inderdaad spesifiek 'n punt daarvan gemaak om die klem op die "gekonstrueerde" eienskap van die toneelpoppe te plaas - dat hulle maaksels is. Hy het probeer om die poppemakers weg te lei van die weerspieëling van realiteit, weg van 'n soomlose veritas. Kentridge wou juis skreiende jukstaposisies tot stand bring. In die woorde van Handspring se poppemaker, Kohler (2009:78), verkies Kentridge "his layering of images and meanings, however seemingly awkward and arcane, to rub against each other".

Woyzeck on the Highveld was die eerste werk waarin Kentridge met Handspring saamgewerk het en hy het hulle gevra om hulle toneelpoppe "ruwer" te maak - 'n versoek wat gelykertyd terug- en vorentoe kyk. Dit kyk terug in die sin dat dit voorkom asof dit ongesofistikeerd en primitief is - en tog is dit ook "nuut" aangesien dit die toneelpoppe laat lyk asof hulle "nuut gemaak" is; asof hulle nog die tekens van 'n onvolmaakte menslike vervaardigingsproses vertoon. Hierdie onafgewerkte beitelwerk staan moontlik in ' $n$ ironiese paradoks teenoor moderniteit. Dit dui 'n handgemaakte proses aan wat in teenstelling staan met die verfynde doelwitte van die masjien.

As agtergrond tot die opvoering het Kentridge rudimentêre houtskoolanimasies gemaak deur 'n proses wat hy "protofilmmaking" noem. Hoewel hierdie tegniek na 'n ouer gebruik terugverwys, verbind dit Kentridge se stilistiese benaderings ook met die avantgarde-estetika: met Ezra Pound se uitspraak, "make it new", waarna Jameson (2002:121) verwys as "the supreme value of the New that seems to preside over any specific or local modernism worth its salt". Hierdie toneelpoppe lyk dus asof hulle nuut gemaak is, al is hulle deur 'n outydse proses gevorm.

Poppespel behels 'n eienaardige vermenging van genres. Aan die een kant is beeldhou die mees Apolliniese van die kunste - 'n studie van suiwer vorm. Aan die ander kant is die opvoering (performance) die geboorteplek van die Dionisiese in die kuns: dit behels die onvoorspelbaarheid van verandering en die transformasie van beweging - die chaos van die tydelike. Om hierdie teenstrydige impulse saam te bring deur aan 'n lewelose voorwerp lewe, spraak en beweging te gee, put uit sowel antieke as moderne tradisies van waarneming en voorstelling. Daar is 'n verbintenis met die antieke wêreld 
in die sin van 'n eerbewys aan die rigiede maskers van die Griekse teater sowel as die idee van die self as 'n voorwerp. Dit verwys ook na die moderne wêreld wat deels gekenmerk word deur die toenemende gebruik van masjinerie, met 'n toenemende meganiese kwaliteit.

Teen die einde van die oorspronklike Pinocchio-roman deur C. Collodi (2005 [1883]), wanneer die toneelpop 'n mens word, word hy 'n loonslaaf, 'n werker in die "regte wêreld" waartoe hy so graag wou behoort. Harold B. Segel (1995:42) redeneer Pinocchio is "destined to become far more of a puppet once he enters adulthood than he was as a puppet". Richard Mitchell (2000:157) dui aan dat "the puppet's dream of becoming an acceptable human, a bourgeois individual, is more alienating and constricting than remaining an inanimate piece of wood". Dit lyk asof dit baie moeiliker is om vryheid te verwesenlik as om teen die stelsel te rebelleer. Om die sosiale toutjies wat 'n mens se lewe beheer, los te ruk in 'n daad van bevryding, is uiters ironies, aangesien dit juis ook 'n daad is wat bemagtiging kortwiek.

Dit is moontlik dat dieselfde gebeur in die prosesse van individualisering. Die Hongaarse filosoof E.M. Cioran (1992:137) skryf: "it is by suffering ... that one ceases to be a marionette". Indien 'n mens weier om 'n voorwerp te wees, kan jy dit vermy om gemanipuleer te word; om uit die samelewing verwyder te word, sou egter waarskynlik wel beteken dat 'n mens gaan swaarkry. Wanneer jy opstandig is, kan jy wel losruk uit sosiale beperkings; tog kan dit op die lange duur ook teen jou beste belange tel. Vryheid is dus nie altyd in ooreenstemming met geluk nie. Segel (1995:23) stel dat:

Suffering from the delusion that they are capable of determining their own actions, human beings merely betray their essential puppetlike nature. Life, in Büchner's view, is absurd; nothing one does can alter that fact, and the more one tries, the more one comes to resemble a puppet or marionette whose actions are determined by forces, or elements, beyond its control.

\section{Gevolgtrekking}

In hierdie artikel is gepoog om die toneelpop te defineer, nie net as 'n uitbeelding van 'n modernistiese samelewing nie, maar ook as 'n tegnologie, 'n masjien wat betekenis produseer. Met hierdie idée gaan die neiging gepaard dat akteurs self in toneelpoppe verander om 'n rol te speel wanneer hulle 'n wêreld uitbeeld. Die toneelpoppe is self voorstellings van betekenis en ook die tegnologie waardeur 
betekenis sinvol voorgestel word. Woyzeck on the Highveld is in hierdie sin 'n toepaslike uitbeelding - 'n voorbeeld van die modernisme in Suid-Afrika. Om hierdie moderniteit deur die gebruik van toneelpoppe te bewerkstellig, skep nog 'n betekenislaag. In hierdie geval is dit nie 'n vervreemdingstegniek nie, maar iets waarin die ongelooflike erken word. In hierdie sin is die vreemdheid ook bekend en die publiek herken dit en word gelei tot soortgelyke gevoelens van vervreemding. Ironies genoeg word die vervreemding hier uitgebeeld as iets wat mense nader aan mekaar trek deurdat hulle saam 'n herkenbare gevoel van vervreemding identifiseer.

Daar is moontlik 'n verband hier met die mensgemaakte wese in P.G. du Plessis se toneelspel, Plaston (1973), waarin 'n professor 'n kind in 'n proefbuis skep. Die seun het nie biologiese ouers nie, maar hy is gemaak om heeltemal menslik op te tree. In baie opsigte is hy soos Pinnocchio in sy begeerte om in die samelewing geïntegreer te word. Hierdie seun is egter ook baie anders as Pinnocchio, aangesien dit vir hom onmoontlik is om 'n leuen te vertel. Hierdie onvermoë is ook sy ondergang. Hy reageer direk op sy instinkte en sê presies wat hy dink, byvoorbeeld wanneer hy vir 'n sewentienjarige meisie sê "Ek wil met jou paar" (Du Plessis, 1973:33). Later bely hy "Ek is te oop gebou" (Du Plessis, 1973:53).

Uit hierdie oogpunt is sosialisering afhanklik van die vermoë om te verberg, om te kry wat 'n mens wil hê deur middel van die rolspel van etiket. In ooreenstemming hiermee word die Woyzeck-toneelpop terselfdertyd minder én meer menslik deur moord te pleeg. Aan die een kant is hy nie in staat om sy drange te onderdruk nie, maar aan die ander kant is daar 'n verskriklike eerlikheid in sy onderliggende aggressiewe impulse. Daar is 'n soort skrikwekkende eerlikheid aan Plaston en Woyzeck daarin dat albei op hulle donkerder begeertes reageer. In hulle pogings om menslik te word, skei hulle hulself van die menslike samelewing af. Deur die masker van die sosiaal aanvaarbare en die beleefdheid te verwyder, word hulle meer as net voorwerpe; hulle word individue.

Hierdie is 'n redelike sombere uitkyk op die beskawing, en tog onderstreep dit wat Siegmund Freud in Civilization and its discontents (1996) sê, naamlik dat mense onrustig voel in die samelewing, want hulle diepste begeertes word om elke draai gefnuik. Tog is die skuldgevoelens wat hiermee gepaard gaan volgens Freud nodig, want sonder hierdie beperkings sal die samelewing vernietig word. Alhoewel ons nie hierdie optrede kan aanvaar nie, is daar tye dat ons karakters soos Woyzeck en Plaston bewonder vir hulle moed 
om hulle teen maatskaplike beperkings te verset. Soos Freud $(1996: 218)$ dit stel:

And we may well heave a sigh of relief at the thought that it is nevertheless vouchsafed to a few to salvage without effort from the whirlpool of their own feelings the deepest truth, towards which the rest of us have to find our way through tormenting uncertainty and with restless groping.

Die toneelpop in Woyzeck onthul die idee van die mens as 'n voorwerp of 'n masjien. Dit verwys na die mens se strewe om meer te wees as net 'n toneelpop, meer as net 'n masjien of iets meganies, en meer as die gefragmenteerde herhalende self wat die moderniteit vir hom/haar as geboortereg gegee het. Die objektivering van die modernistiese self kan dus moontlik gesien word as 'n demonstrasie van die wyses waarop vryheid en die beperkings van vryheid, voorgestel kan word in 'n wêreld waarin die magte wat ons belewenis van die self beheer, versterk word omdat hulle grotendeels onsigbaar is.

\section{Geraadpleegde bronne}

BORDO, S. 1996. The Cartesian masculinization of thought. (In Cahoone, L., ed. From modernism to postmodernism: an anthology. Cambridge: Blackwell. p. 638-664.)

BÜCHNER, G. 1971 [1879]. Danton's death, Leonce and Lena, Woyzeck. Trans. by V. Price. Oxford: Oxford University Press.

BÜCHNER, G. 1992. Woyzeck on the Highveld. Mark Theatre production. [Video.]

CIORAN, E.M. 1992. Anathemas and admirations. Trans. by R. Howard. Londen: Quartet Encounters.

COLLODI, C. 2005 [1883]. The adventures of Pinocchio. Trans. by E. Harden. Berkeley: University of California Press.

DU PLESSIS, P.G. 1973. Plaston - DNS kind. Kaapstad: Tafelberg.

DU PREEZ, P. 2007. Ikoon en medium: die toneelpop, masker en akteurmanipuleerder in Afrika-performances. Stellenbosch: Universiteit van Stellenbosch. (Ph.D.-proefskrif.)

FREUD, S. 1996. Civilization and its discontents. Trans. by J. Strachey. (In Cahoone, L., ed. From modernism to postmodernism: an anthology. Cambridge: Blackwell. p. 212-218.)

JAMESON, F. 2002. A singular modernity: essay on the ontology of the present. Londen: Verso.

KOHLER, A. 1992. Woyzeck on the Highveld. (Unpublished drama text.)

KOHLER, A. 2009. Thinking through puppets. (In Taylor, J., ed. Handspring Puppet Company. Parkwood: Krut. p. 42-249.)

MARX, G. 2009. A matter of life and death: the function of malfunction in the work of Handspring Puppet Company. (In Taylor, J., ed. Handspring Puppet Company. Parkwood: Krut. p. 225-249.) 
MARX, K. 1988. Economic and philosophic manuscripts of 1844. Trans. by Martin Milligan. New York: Prometheus Books.

MITCHELL, R.W. 2000. Book review: Pinocchio's progeny. The drama review, 44(2):155-157.

SEGEL, H.B.1995. Pinocchio's progeny: puppets, marionettes, automatons, and robots in modernity and avant-garde drama. Baltimore: Johns Hopkins University Press.

SMALBERGER, L-M. 2011. The exploration, creation and transmission of gender codes in puppetry through the practical exploration of Cleansed Playing Sex. Stellenbosch: University of Stellenbosch. (M.Dram. thesis.)

\section{Kernbegrippe:}

Büchner, Georg

Handspring Puppet Company

identiteit

Kentridge, William

modernisme

self

toneelpoppe

vryheid

Woyzeck on the Highveld

\section{Key concepts:}

Büchner, Georg

freedom

Handspring Puppet Company

identity

Kentridge, William

modernism

puppets

self

Woyzeck on the Highveld 
